\title{
УДОСКОНАЛЕННЯ ПРОФЕСІЙНОЇ ПІДГОТОВКИ МАЙБУТНІХ ПЕДАГОГІВ ПРОФЕСІЙНОГО НАВЧАННЯ ВІДПОВІДНО ДО ТРЕНДІВ РИНКУ ПРАЦІ
}

\begin{abstract}
Анотація. У статті схарактеризовано сучасні вимоги до підготовки майбутніх педагогів професійного навчання за спеціалізацією 015.36 Професійна освіта (Технологія виробів легкої промисловості). На основі аналізу науково-теоретичних праць учених і реальної практики використання інноваційних текстильних матеріалів, виокремлено основні з них, а саме: електронний текстиль, активний текстиль, еко-технічний текстиль, теплоізоляційні матеріали, нанотехнології як один з елементів сучасних виробничих процесів волокнистих матеріалів (текстильні полотна, шкіра, штучна шкіра, хутро, штучне хутро та інші). Здійснено доповнення змісту освітнього компоненту (ОК) «Матеріалознавство швейного виробництва», який вивчають майбутні педагоги професійного навчання за спеціалізаціею 015.36 Професійна освіта (Технологія виробів легкої промисловості)» темою лекційного курсу «Інноваційний текстиль та активні матеріали». Ключові слова: підготовка, майбутні педагогі професійного навчання, електронний текстиль, активний текстиль, еко-технічний текстиль, теплоізоляційні матеріали, нанотехнології.
\end{abstract}

Marynchenko Inna, Vasenok Tetiana, Zinchenko Albina Oleksandr Dovzhenko Hlukhiv National Pedagogical University

\section{IMPROVEMENT OF PROFESSIONAL TRAINING OF FUTURE PROFESSIONAL TEACHERS IN ACCORDANCE WITH LABOR MARKET TRENDS}

Summary. The article describes the current requirements for the training of future teachers of vocational training in specialization 015.36 Vocational education (Technology of light industry products). It was found that the garment industry has recently used fabrics that are lighter, thinner and more porous, have a more sparse structure, and the manufacture of products from these materials by classical technology does not provide high quality, sufficiently stable three-dimensional shape of the finished product. and its competitive appearance. Based on the analysis of scientific and theoretical works of scientists and real practice of using innovative textile materials, the main innovative textile materials of the new generation are identified, namely: electronic textiles, active textiles, eco-technical textiles, thermal insulation materials, nanotechnology as one of the elements of modern production processes. (textile fabrics, leather, artificial leather, fur, artificial fur and others). It is determined that the traditional range of fabrics and materials is changing and replenished due to the optimal selection of the necessary types of raw materials, changes in their structure, widespread use of new types of finishes and special treatments. The range of functional finishes is expanded, the comfort and protective properties of fabrics are increased, which completely eliminates the problems of caring for them. The content of the educational component (OK) «Materials science of garment production», which is studied by future teachers of vocational training in specialization 015.36 Vocational Education (Technology of light industry products) «theme of the lecture course" Innovative textiles and active materials». It is determined that today there are many areas where ecotextiles are used: fabric that disinfects the surrounding air with ultraviolet radiation produced by Brochier optical fibers; the use of textiles in the production of biofuels from microalgae in the project "Curtain of Algae" by a group of London designers called Loop.

Keywords: training, future teachers of vocational training, electronic textiles, active textiles, eco-technical textiles, heat-insulating materials, nanotechnologies.

$\Pi^{2}$ остановка проблеми. Процес реалізації стратегічних завдань до підготовки майбутніх педагогів профресійного навчання за спеціаалізацією 015 Профресійна освіта (Технологія виробів легкої промисловості) вимагає нових підходів щодо переходу кількісних показників її рівня в якісні. Проблеми підготовки висококваліфрікованого робітника актуальні як в Україні, так і за ії межами. Важливого значення набуває створення умов підготовки майбутніх педагогів професійного навчання конкурентоспроможних на ринку пращі на засадах використання інноваційних методів виготовлення тканин нового покоління [7].

Визначальними фракторами позитивних змін у профресійній освіті $є$ розвиток технологій та урбанізація, що окреслюють «правила гри» для всіх учасників освітнього ринку, спонукаючи їх до впровадження новітніх освітніх моделей, методик, технологій тощо. Нові технології обумовлюють цивілізаційний розвиток людства впливають на якість життя людей в усьому світі, незалежно чи це велике місто чи віддалене сілььке поселення.

Зважаючи на це, видозмінюеться загальна мета освіти. Головним завданням освітніх процесів у сучасних закладах вищої освіти має бути розвиток вміння мислити, самостійно здобувати інформацію і критично їі оцінювати, а не лише накопичувати і запам'ятовувати її [13].

Сучасний ринок пращі висуває нові вимоги до змісту і процесу профресійної підготовки майбутніх педагогів продресійного навчання за спеціалізацією 015.36 Профресійна освіта (Технологія виробів легкої промисловості). Працівник сьогодення повинен мати глибокі профресійні знання, володіти основами наукової організації праці і культури виробництва; бути здатним до технічної та соціальної творчості, до проектування власної діяльності в різних соціокультурних ситуаціях, самовдосконалення, готовим знаходити шляхи рішення проблем незалежно від поодиноких обста- 
вин, до роботи при різних фрормах організації праці і виробництва в жорстких умовах конкуренції, спроможним виробляти особливу стратегію професійного мислення, поведінки і діяльності [2].

Активний розвиток науки та просування передових технологій на сучасному етапі стало основою для формування нової галузі знань - інноващійного матеріалознавства та стало причиною появи нової категорії матеріалів так званих «розумних тканин». Їх особливість полягає у реакції на зміну стану навколишнього середовища, а також полягає у здатності змінювати свої властивості залежно від зовнішніх фокторів. «Розумні» матеріали комфортніші, ніж традищійні: гріють у мороз, охолоджують у спеку і навіть змінюють розміри залежно від температури. У дизайні костюма та експериментальному дизайні застосування нових тканин сприяе розробці унікальних багатофункціональних об'єктів, що не мають аналогів у дизайнерській практиці. «Розумні матеріали» іноді являють собою цілий програмно-апаратний комплекс, що складається з усіляких сенсорів, мініатюрних процесорів та виконавчих наноустроїв [10].

Виходячи 3 розвитку технологій та створення інноваційних текстильних матеріалів вимагається оновлення освітніх компонентів освітньої програми першого (бакалаврського) рівня 015.36 Профресійна освіта (Технологія виробів легкої промисловості).

Матеріалознавство швейного виробництва (МШВ) - це навчальна дисципліна, що вивчає будову, властивості, асортимент і якість швейних матеріалів, їх зміну в результаті різних впливів у виготовленні швейних виробів та експлуатації. Особливістю викладання дисципліни $є$ те, що вона містить велику кількість кросдисциплінарних понять, які формують підгрунтя для навчання майбутніх педагогів професійного навчання за спеціалізацією 015 Профресійна освіта (Технологія виробів легкої промисловості) практикуму 3 обробки текстильних матеріалів, технології пошиття виробів, конфрекціюнування у швейному виробництві, виготовлення та оздоблення виробів у різних техніках декоративно-ужиткового мистецтва тощо. Таким чином, змістове наповнення навчальної дисципліни слід формувати 3 урахуванням сучасного розвитку у галузі матеріалознавства виробів легкої промисловості. Саме тому підготовка майбутніх педагогів професійного навчання має відповідати тенденщіям інноваційного розвитку у галузі швейного матеріалознавства [5;8].

Аналіз останніх досліджень і публікацій. Питання методики навчання матеріалознавства швейних виробів досліджені недостатньо, переважно їх розкривали такі науковці як О. Гнеденко, Л. Хоменко. Важливу роль у підготовці здобувачів профресійної освіти швейної галузі відіграє зміст дисципліни «Матеріалознавство швейного виробництва", формуванням якого займалися такі науковці, як: Н. Алимепкова, Е. Амірова, Б. Бузов, Т. Волинець, Е. Дрегуляс, 3. Кучер, С. Кучер, К. Лазур, Т. Модестова, Л. Орленко, О. Патлашенко, Н. Савостицкий, 3. Семак, А. Слізков, Н. Супрун, Ю. Шустовта інші.

Ціль статті. Дослідження результатів впровадження інноваційних текстильних матеріалів у підготовку майбутніх педагогів профресійного навчання за спеціалізацією 015 Продесійна освіта (Технологія виробів легкої промисловості).

Виклад нового матеріалу. Подальший розвиток продресійної (продесійно-технічної) освіти України не можливий без досягнення европейського рівня освітніх стандартів з урахуванням національних особливостей, що обумовлюе необхідність модернізації та розширення фрункцій П(ПТ)О. Для досягнення європейського рівня підготовки педагогів профресійного навчання за спеціалізацією 015.36 Профресійна освіта (Технологія виробів легкої промисловості) слід широко використовувати інноваційні технології виготовлення матеріалів нового покоління [4].

За таких умов значно збільшуються вимоги до якості навчання педагогів професійного навчання у закладах вищої освіти, ключовим чинником забезпечення якої виступає професійна діяльність педагогічних та науково-педагогічних працівників. На часі в Україні актуалізуеться проблема системної модернізація професійної освіти і навчання, що створить передумови для сталого розвитку суспільства, підвищення конкурентоспроможності економіки країни, професійного зростання та самореалізації особистості [3].

Швейна промисловість останнім часом використовуе тканини, що є більш легкими, тонкими та пористими, мають більш розріджену структуру, а виготовлення виробів 3 цих матеріалів за класичною технологією не забезпечує високої якості, достатньо стійкої об'ємно-просторової форми готового виробу та його конкурентоспроможного вигляду [11].

Запорукою підвищення ефективності швейного виробництва є глибоке знання швейних матеріалів та їх властивостей, розробка сучасних конструкцій одягу на підставі підбору режимів обробки матеріалів за їх волокнистим складом, будовою, асортиментом і призначенням. Усі ці питання є предметом вивчення швейного матеріалознавства.

На найближчі роки в Україні визначено генеральну лінію розвитку швейних матеріалів. Це, перш за все, максимум комфорту та різноманітність можливостей застосування швейних матеріалів, їх легкість, компактність, формостійкість, пластичність, гігієнічність тощо і, як наслідок мінімум проблем для споживача.

Традищйний асортимент тканин і матеріалів змінюеться та поповнюеться за рахунок оптимального добору необхідних видів сировини, зміни їх будови, широкого використання нових видів оздоблення та спеціальних обробок. Розширюеться спектр функціонального оздоблення, підвищується комфортність і захисні властивості тканин, що повністю ліквідуе проблеми догляду за ними. Водночас велика увага приділяеться декоративним ефектам: багатству фрактури тканин та матеріалу, виразності рельефу та блиску, складній орнаментащії тощо [6].

В процесі масового та індивідуального швейного виробництва використовують різноманітні швейні матеріали. Головним постачальником матеріалів для швейної промисловості $є$ текстильна промисловість.

У різноманітній палітрі текстильних виробів технічного призначення, починаючи з 1990 року, виділилися кілька інноваційних напрямків під загальною назвою «нео-текстильні вироби». Ця група охоплюепрактично всі новітканини, у томучислі матеріали 3 активними фрункціями. Сьогодні існують 
три сімейства подібних матеріалів: електронний текстиль, текстиль 3 активними властивостями та еко-техно текстиль. Істотною характеристикою електронних текстильних виробів $€$ наявність джерела живлення для здійснення їх споживчих функщій. Електронні текстильні матеріали та активні текстильні матеріали з'явилися одночасно, у 1990-х роках. Еко-техно текстиль, який утворив нову категорію матеріалів, виник нещодавно, на початку 2010-х років. Він є фрлагманом еко-технології, його застосування дозволяє розвивати природоохоронну діяльність за допомогою відновлення та захисту навколишнього природного середовища [10].

Основним напрямком удосконалення якості текстильних матеріалів у 2021 році є покращення їх теплоізоляційних властивостей. Більшість сучасних теплоізоляційних матеріалів мають багатошарову структуру. Окремі шари матеріалів з різними фрізико-хімічними властивостями дозволяють оптимізувати характеристики теплоізоляції шляхом зміни товщини та порядку шарів [12].

Електронний текстиль $є$ матеріалом, що проводить і одночасно споживає електричну енергію. Він об'єднав дві раніше самостійні області: текстиль та електроніку. Текстильний матеріал $€$ основою, де встановлюються різноманітні електронні пристрої. Іноді текстиль включає різні датчики і контактні кабелі. Схематично електронний пристрій складається 3 мікроконтролера, підключеного до зовнішнього пристрою, що є датчиком, перемикачів, батарей живлення і зовнішніх пристроїв, таких як колонки, дисплеї, світлодіоди, електролюмінесцентні екрани, об'єктиви і т.п.

Активний текстиль не потребуе живлення для свого фрункціонування. Такий матеріал широко використовуеться в текстильній, косметичній, хімічній та парфумерній галузі. Як і в електронному текстилі, тканина фороме переважно підкладку, на якій дана технологія і застосовується. Зовнішній шар може бути нанесений за допомогою друку або хімічного оздоблення, тобто вологим способом; шляхом заповнення (занурення тканини у ванну) або розпорошення. Найбільш поширені технології пов'язані 3 інтегруванням у тканину ароматних молекул, косметичних або термохромних волокон у вигляді мікрокапсул для запобігання неприемним запахам, для збереження тепла та створення едекту люмінесценщії. Ці тканини мають два режими роботи: активний та пасивний. Матеріали є оборотними, вони здатні змінювати зовнішній вигляд та повертатися до свого первісного стану, змінюючи такі зовнішні параметри, як температура, вологість чи тиск. Вони здатні реагувати на індивідуальний стан користувача, змінюючи свій колір та форму.

Третім сімейством текстильних виробів, що володіє активними фонкціями, є еко-технічний текстиль. Слід зазначити, що цей напрямок виробництва не передбачає просту "вторинну переробку» самого продукту. Воно пов'язані з урахуванням обмежень розробки завдань на проектування і за подальшому виготовленні текстилю, застосовуваного всім областей. Еко-техно текстиль передбачає використання нових оригінальних технологій у поєднанні з еко-відповідальність, що виходить за рамки життевого циклу самого матеріалу. На даний момент запроваджено лише невелику кількість подібних проектів. Але завдяки творчості і науковому пошуку дослідників народжу- ється нове сімейство матеріалів, що заслуговує на уважний розгляд. Без сумніву, процес створення подібних тканин великою мірою руйнуе стереотипи, що склалися. Ці текстильні вироби здебільшого перебувають у процесі маркетингових досліджень. Еко-текстиль розробляеться на основі партнерства між промисловими дизайнерами та науково-дослідними лабораторіями [1].

Нанотехнології як одним 3 елементів сучасних виробничих процесів волокнистих матеріалів (текстильні полотна, шкіра, штучна шкіра, хутро, штучне хутро та інші) сприяють створенню нових спеціальних допоміжних препаратів для оброблення (нанопокриття) поверхонь текстильних матеріалів. Внутрішня структура, сформована 3 наночастинок, надає матеріалам значно вищу міцність і зовсім нові властивості, відсутні за умов створення матеріалу за традищійною технологією. Покриття на основі наночасток запобігають забрудненню тканин, а також сприяють iii обеззаражуванню. За допомогою нових наноповерхонь самоочистка матеріалів, у тому числі текстилю, може відбуватися в звичайних умовах. Ефект самоочищення після нанесення наношару діє протягом всього життевого циклу одягу.

Інноваційні текстильні матеріали, вироблені за високими технологіями, можна поділити на дві групи.

До першої групи віднесемо ті тканини, властивості яких $є$ статичними, тобто властивості їх, такі як забарвлення, тепло-, електропровідність та інші, не змінюються залежно від викликів зовнішнњого середовища чи користувача одягу. Вони пасивно підтримують відчуття комфрорту та емощійного задоволення. Тобто, щоб змінити щось в одязі, потрібно замінити тканину на іншу, але неможливо змінити, відповідно до зміни обставин, властивості тканини. Змінюеться стан навколишнього середовища - необхідно змінювати одяг. Цю групу тканин називають просто високотехнологічними тканинами.

Друга група тканин, вироблених за високими технологіями, спроможна активно реагувати на виклики внутрішнього та зовнішнього середовища. Їхні властивості стали динамічними. Такий текстиль називають «інтелектуальним», «розумним», який може змінювати колір під дією тепла або світла, після багаторазових прань продовжувати виділяти приемні аромати, вітаміни, ліки, захищати від мікробів, виробляти електроенергію для «своєї» електроніки, дистанційно передавати біометричну інформацію та ін. [9].

Розглянемо декілька прикладів упровадження інноващійних матеріалів у текстильну галузь i виробництво високотехнологічного одягу, наведених як симбіоз текстилю, мікроелектроніки й спеціальних хімічних речовин.

Мелбранні тканини поєднують у собі водонепроникні, вітрозахисні та дихальні властивості. Використання сучасних технологій дало змогу одержувати надзвичайно тонкі мікроволокна, які майже у 10 разів тонші людського волоска. Виготовлені з мікроволокна трикотажні полотна - Polartec (фрліс) - перевершили за теплозахисними властивостям традищійний матеріал - вовну. При џому Polartec набагато легший, не набирає вологи і захищає від вітру. Вироби з Polartec без додаткового оброблення не промокають під дрібним дощем. Всі ці якості тканин групи Polartec можливі завдяки вико- 
ристанню сучасних технологій, а саме - поліестерового мікроволокна, спеціального плетіння тканини та оригінального кінцевого оброблення.

Нанотекстиль $i$ хутро. Під нанотекстилем найчастіше розуміють тканину, вироблену з традищійних волокон, оброблену наночастками певних хімічних речовин, внаслідок чого вона набуває нових експлуатаційних властивостей: нанотекстиль здатен до самоочищування (протистояння забрудненню), знищення бактерій, розкладання бруду і поту, легкого пропускання вологи назовні, відштовхуючи зовнішню воду. За різними технологіями для нанообробки текстилю використовуються наночастки срібла, паладію та діоксиду титану. Найпростішою в обробленні тканиною є бавовняна. Найбільш трудомісткими матеріалами є вовна та шовк.

Нанотехнології застосовуються й в обробщі хутра. Фізики вирішили завдання нанесення атомів золота на хутро: рухаючись із швидкістю декількох кілометрів на секунду, атоми міцно зчіплюються 3 атомами ворсинок хутра. При цьому хутро не втрачає своєї м'якості і краси. З'являються нові переваги: воно стійкіше до зносу і вологи, набуває антибактеріальних і антиалергенних властивостей. Змінюючи розмір наночастинок чистого золота та срібла при обробленні хутра, мериносової вовни, залежно від співвідношення елементів, полотно (не обов'язково шерстяне) забарвлюеться у найрізноманітніші кольори: від жовтого до фріолетового. Змінюючи співвідношення золотих і срібних включень, можна варіювати інтенсивність відтінку.

Електрогенеруючі тканини. Останне десятиліття у швейному виробництві широко використовуеться принцип перетворення дії зовнішніх факторів на текстиль в електроенергію, зокрема у виготовленні верхнього одягу, спецодягу, виробів спортивного призначення, наприклад для туризму. Використовуються термоелементи та акумулятори для забезпечення комфортного теплового режиму в умовах низьких температур; гарантія безпеки на воді за рахунок автоматичного вмикання піддуву м'якої оболонки, вшитої в одяг. Одяг спещпризначення та побутовий може оснащуватись різними пристроями, повинні мати мінімальну вагу та габарити. Такі характеристики мають сонячні батареї, які зараз широко використовуються і постійно вдосконалюються. На модному показі у Флоренції була представлена спортивна куртка, у комір якої були вшиті сонячні елементи, а вироблена енергія передається через вплетені в структуру тканини дротики на невелику вбудовану літій-іонну батарею, або відразу на сам мобільний пристрій. Така батарея заряджається приблизно 8 годин, а батарея мобільного теледрону - всього за 4 години.

Тканина-халелеон, тканина-дисплей. Нині виробляються фрункціональні барвники - фрото-, термо-, гідрохромні, які дають змогу тканині самій змінювати своє забарвлення під впливом світлових променів, температури, вологості. Звичайна синтетична тканина Luminex, у якій поряд 3 іншими нитками підкання, використовуеться особлива синтетична нитка - оптоволокно, здатне проводити світло. Джерелами підсвічування є світлодіоди, що приеднуються до оптоволокна, яка і розподіляе світло по всій поверхні тканини. Компанія Lumalive Philips пропонує світлодіод- ну тканину, яка за структурою та наділеними світлоедектами еволюційно перевершує тканину Luminex. Philips винайшли тканину, здатну світитись завдяки великій кількості вмонтованих LED-світлодіодів, що надали тканині здатність не тільки переливатись найрізноманітнішими кольорами, а й відображати як статичні, так і динамічні зображення. У результаті цього тканину можна використовувати як дисплей.

Високотехнологічні тканини для лікування $i$ колоборту. Давно відомі листівки із запахом (який відчувається, якщо потерти папір) i ароматизовані рекламні сторінки в журналах. У цих випадках застосовуються міріади мікрокапсул з активною речовиною, які вбудовуються в матеріал. Під час натискання або тертя частина капсул руйнуеться, випускаючи парфум на волю. Для створення таких мікрокапсул застосовувався фрормальдегід, відомий як екологічно небезпечна сполука.

На сьогодні є багато областей, де вже застосовується екотекстиль: наприклад, це тканина, що знезаражуе навколишне повітря за допомогою ультрафріолетового випромінювання, що проводиться за допомогою оптичних волокон Brochier; це використання текстилю у виробництві біопалива із мікроводоростей у проекті «Завіса 3 водоростей» групи лондонських дизайнерів під назвою Loop. Деякі з подібних проектів є частиною колекцій WattWatch ${ }^{\mathrm{TM}}$, що належить Marithé et Francois Girbaud. Цікаво відзначити, що більшість досліджень проводиться в галузі обробки тканин, обраного як стратегічний напрям для творчості та для врахування екологічних фракторів, пов'язаних 3 охороною навколишнього середовища [10].

Зважаючи на сучасні тенденції розвитку інноваційних матеріалів у текстильній галузі, виробництво високотехнологічного одягу, створення сучасних матеріалів, трендів у моді існує потреба оновлення освітніх компонентів за освітньою програмою першого (бакалаврського рівня) за спеціалізацією 015.36 Профресійна освіта (Технологія виробів легкої промисловості). Таким чином, вважаємо за необхідне доповнити зміст освітнього компоненту $(\mathrm{OK})$ «Матеріалознавство швейного виробництва», яку вивчають майбутні педагоги профресійного навчання за спеціалізацією 015.36 Профресійна освіта (Технологія виробів легкої промисловості)» темою лекційного курсу «Інноваційний текстиль та активні матеріали».

Висновки й пропозиції. Текстильні матеріали порівняно з матеріалами, що використовуються в інших галузях промисловості, мають особливі специфрічні властивості: механічні, фрізичні (гігієнічні), технологічні; виготовлення виробів 3 текстильних матеріалів вимагає від працівників спеціальних знань їхніх властивостей, а також уміння практично використовувати ці знання в технологічних процесах швейного виробництва. Фізико-механічні і фрізико-хімічні властивості тканин і матеріалів, що випускае текстильна промисловість нині, суттево відрізняються від властивостей тих тканин і матеріалів, з якими кравещ і закрійник працював вчора; вони певним чином впливають на специфіку його праці. Лише фрормування цілісної системи знань про властивості швейних матеріалів на засадах інтегращії є підірунтям для формування у майбутніх педагогів професійного навчання цілісного системного поняття про основний предмет праці. 


\section{Список літератури:}

1. Бост Ф., Кросетто Г. Инновационный текстиль и активные материалы. Международный научно-исследовательский журнал. 2014. № 2. С. 22-33.

2. Васенок Т.М. Шелудько І.В. Проектування як засіб формування професійної компетентності майбутніх викладачів спец предметів ПТНЗ. Вісник Глухівського національного педагогічного університету імені Олександра Довженка. 2017. Випуск 2(34). С. 101-107.

3. Ковальчук В.І., Федотенко С.Р. Інноваційні технології навчання - основа модернізації професійної освіти. Молодий вчений. 2018. № 12. С. 425-429.

4. Ковальчук В.І., Бирка М.Ф. Методичні рекомендації до курсу «Інформаційні технології» у ПТНЗ. Професія «Кравець». Київ : ТОВ «Майстерня книги», 2010. 136 с.

5. Ковальчук B.I. Ефективний урок: технології, структура, аналіз. Київ : Шкільний світ, 2011, 120 с.

6. Лазур К.Р. Швейне матеріалознавство : підручник. Львів : Світ, 2003. 240 с.

7. Маринченко I.В. Упровадження цифрових технологій у підготовці майбутніх педагогів профресійного навчання художнього профілю. Мистецька освіта: зліст, технологї, менеджмент. Серія : Педагогічні науки : зб. наукових праць. 2020. Вип. 15. С. 173-187.

8. Марущак О.В. Інтеграція знань з матеріалознавства у професійній підготовці майбутніх фрахівців швейного виробництва : дис. ... канд. пед. наук : 13.00 .04 «Теорія і методика професійної освіти»; Вінницький державний педагогічний університет ім. Михайла Коцюбинського. Вінниця, 2005. 255 с.

9. Марущак О. Проектно-технологічна діяльність у професійній підготовці майбутніх учителів технологій 3 дизайну костюма. Збірник наукових праць Уманського державного педагогічного університету. 2013. Ч. 3. С. $165-172$

10. Назаров Ю.В., Попова В.В. Инновационный текстиль. Основные виды и области применения. Международный научно-исследовательский журнал. 2014. № 10(52). Часть 2. С. 172-174.

11. Пашкевич К.Л. Проектування тектонічних форм одягу з урахуванням властивостей тканин : монографрія. Київ : ПП «НВЦ «Профрі», 2015. 364 с.

12. Alexander Zasornov, Iryna Zasornova and Inna Marynchenko Experimental investigation of multilayer thermal insulation material performance with using of discrete heat transfer model. Fibres and Textiles. 2020. Vol. 4. P. 138-145.

13. Kovalchuk V., Marynchenko I. Implementation of digital technologies in training the vocational education pedagogues as a modern strategy for modernization of professional education. Annales Universitatis Paedagogicae Cracoviensis. Studia ad Didacticam Biologiae Pertinentia. 2019. Vol. 1. Issue 9. P. 122-138.

\section{References:}

1. Bost F., Crosetto G. (2014) Textiles innovations et matieres actives [Innovative textiles and active materials]. International research journal, no. 2, pp. 22-33 (in Russian)

2. Vasenok T.M., Sheludko I.V. (2017) Proektuvannia yak zasib formuvannia profesiinoi kompetentnosti maibutnikh vykladachiv spets predmetiv PTNZ [Design as a means of forming the professional competence of future teachers of special subjects of vocational schools]. Bulletin of Hlukhiv National Pedagogical University named after Oleksandr Dovzhenko, vol. 2(34), pp. 101-107.

3. Kovalchuk V.I., Fedotenko S.R. (2018) Innovatsiini tekhnolohii navchannia - osnova modernizatsii profesiinoi osvity [Innovative learning technologies are the basis for the modernization of vocational education]. Young scientist, no. 12 , pp. 425-429.

4. Kovalchuk V.I., Byrka M.F. (2010) Metodychni rekomendatsii do kursu "Informatsiini tekhnolohii» u PTNZ. Profesiia - «Kravets» [Methodical recommendations for the course "Information Technology" in vocational schools. Profession - "Tailor"]. Kyiv: Book Workshop LLC, p. 136. (in Ukrainian)

5. Kovalchuk V.I. (2011) Efektyvnyi urok: tekhnolohii, struktura, analiz [An effective lesson: technology, structure, analysis]. Kyiv: School world, p. 120. (in Ukrainian)

6. Lazur K.R. (2003) Shveine materialoznavstvo: pidruchnyk [Sewing materials science: a textbook]. Lviv: World, p. 240. (in Ukrainian)

7. Marynchenko I.V. (2020) Uprovadzhennia tsyfrovykh tekhnolohii u pidhotovtsi maibutnikh pedahohiv profesiinoho navchannia khudozhnoho profiliu. [Introduction of digital technologies in the training of future teachers of professional art education]. Art education: content, technology, management. Series: Pedagogical sciences: coll. scientific works, vol. 15, pp. 173-187.

8. Marushchak O.V. (2005) Intehratsiia znan $\mathrm{z}$ materialoznavstva $\mathrm{u}$ profesiinii pidhotovtsi maibutnikh fakhivtsiv shveinoho vyrobnytstva: dys. ... kand. ped. nauk: 13.00 .04 «Teoriia i metodyka profesiinoi osvity»; Vinnytsia State Pedagogical University Mykhailo Kotsyubynsky. Vinnitsa, p. 255.

9. Marushchak O. (2013) Proektno-tekhnolohichna diialnist u profesiinii pidhotovtsi maibutnikh uchyteliv tekhnolohii z dyzainu kostiuma [Design and technological activities in the training of future teachers of technology in costume design] Collection of scientific works of Uman State Pedagogical University, vol. 3, pp. 165-172.

10. Nazarov Yu.V., Popova V.V. (2014) Innovatsionnyiy tekstil. Osnovnyie vidyi i oblasti primeneniya [Design and technological activities in the training of future teachers of technology in costume design]. International Research Journal, no. 10(52). vol. 2, pp. 172-174.

11. Pashkevych K.L. (2015) Proektuvannia tektonichnykh form odiahu z urakhuvanniam vlastyvostei tkanyn: monohrafiia [Design of tectonic forms of clothing taking into account the properties of fabrics] Kyiv: PP «NVTS «Profi», p. 364.

12. Alexander Zasornov, Iryna Zasornova and Inna Marynchenko (2020) Experimental investigation of multilayer thermal insulation material performance with using of discrete heat transfer model. Fibres and Textiles, vol. 4, pp. $138-145$.

13. Kovalchuk V., Marynchenko I. (2019) Implementation of digital technologies in training the vocational education pedagogues as a modern strategy for modernization of professional education. Annales Universitatis Paedagogicae Cracoviensis. Studia ad Didacticam Biologiae Pertinentia, vol. 1, issue 9, pp. 122-138. 